\title{
The Demographic Patterns of Psychoactive Substance Abuse among Secondary School Students in Bosso Local Government Area Niger State, Nigeria
}

\author{
Onyinye Nkiru C. Egbuonu ${ }^{1 *}$ MPHE, Anthony Cemaluk C. Egbuonu² PhD, Efiong S. Samuel ${ }^{1}$ \\ PhD \\ ${ }^{I}$ Department of Health and Physical Education, University of Nigeria Nsukka Enugu State Nigeria \\ ${ }^{2}$ Department of Biochemistry, Michael Okpara University of Agriculture Umudike, Nigeria
}

*Corresponding Author: Onyinye Nkiru C. Egbuonu MPHE, Department of Health and Physical Education, University of Nigeria Nsukka Enugu State Nigeria, Email: nkiruosakwe10@yahoo.com

Abstract: The demographic patterns of psychoactive substance abuse among secondary school adolescents in Bosso Local Government Area, Niger State, Nigeria.

Methods: Cross-sectional survey design was employed to obtain data from the respondents $(n=1820)$, using Psychoactive Substance Abuse Questionnaire (PSAQ) and appropriate statistics (Chi-square $\chi^{2}$ ) at $p<0.05$.

Results: Out of 1719 (100\%) valid respondents, 1175 (68.35\%) and $544(32.65 \%)$ respectively were males and females, hence a Male: Female ratio of 3.15. Age demography, 22 (1.28\%), 831 (48.34\%) and 866 (50.38\%) were in the 10-13 years, 14-16 years and 17-19 years age bracket, respectively. Percentage analysis according to gender revealed that females abused kola nuts (99.6\%) and coffee (89.3\%) more than the male students, whereas higher proportion of males abused the other surveyed psychoactive substances except opium while according age, substance abuse was higher among the 10-13years age bracket for kola nuts (95.5\%) and codeine/cough syrup (95.5\%) and among the 14-16 age brackets for coffee (76.7\%) only but moderately abused among the 17-19 age brackets for cigarette (54.5\%), petrol (47.9\%), marijuana (43.0\%) and alcohol $(38.2 \%)$. There was no significant difference $(p>0.05)$ in the substance abuse according to gender (except for opium) and according to age (except for opium, cannabis and amphetamines).

Conclusion: The demographic pattern of substance among studied adolescents cuts across their age and gender though higher involvement in male gender and 17-19 years age bracket. It was recommended that parents, school authorities and government should disregard age and gender disparity while discouraging the adolescents from substance abuse. Further studies are thus warranted and recommended.

Keywords: Psychoactive substance use, secondary school students, Bosso LGA, Niger State, Nigeria

\section{INTRODUCTION}

Psychoactive substances could modify the moods, behaviours and judgements of such users ${ }^{[1]}$ with possible diverse toxic effects ${ }^{[2-6]}$. Thus, psychoactive substance use, especially among adolescents, is a major public health and social concern. Generally, substance use predates modern history and is widespread in many African countries [7], including Nigeria where tobacco and alcohol act as "gateway drugs" to life use of other substances ${ }^{[8]}$. Adolescence age, between the ages of 10-19 years, is usually secondary school-going age. High rates of substance abuse in secondary school student populations have been reported ${ }^{[9-}$ ${ }^{12]}$. Secondary school is unique in having the high number of teenagers who are seemingly battling with self identity and peer pressure influence are more vulnerable to undertaking even illicit actions ${ }^{[13 ; 14]}$. The study aimed to determine the demographic patterns of some psychoactive substances use among adolescents in Bosso Local Government Area (LGA) in Niger State, Nigeria, using descriptive crosssectional survey design method. This was a follow up to earlier study ${ }^{[15]}$. The result of this study could establish the demographic patterns of use of some substances among the secondary school adolescents in Bosso LGA, Nigeria. This study could provide further insight in the area and basis for substances abuse prevention and policy formulation programs. 


\section{Materials And MethodS}

The study was carried out between 2009 and 2011 as a Masters of Science degree research in the Department of Health and Physical Education, University of Nigeria, Nsukka. Ethical approval and permission were sought and obtained from the Ethical Committee of the Department and the University. The students were informed about the purpose of the study. Consenting students were assured of their safety and confidential use of the outcome for research purpose. Descriptive cross-sectional survey research design was utilized which generally facilitates the description of a situation in its current state and gathers information directly from the subjects. This design was considered appropriate, as it has been used in related studies $[16 ; 17]$.

\subsection{Population of the Study and Sample Size Determination}

The population for the study consisted of all the secondary school adolescents in the twenty one (21) public schools in Bosso LGA, Niger State. Thus, the total population, comprising both males and females, was thirty four thousand four hundred and thirty one $(34,431)$ students as at 2010 as ascertained from the Department of Planning and Statistics, Niger State Ministry of Education, Minna, Niger State.

The sample size for the study, $\mathrm{n}=1,820$, was determined by the multistage sampling procedure. This procedure involved stratifying the fourteen communities where the twenty one schools in Bosso LGA were sited into urban and rural and using the simple random sampling technique to select ten urban and three rural schools, making thirteen schools. The next stage involved cluster sampling of the thirteen schools into junior and senior classes and selected all to twenty six intact classes. With estimated class size of seventy (70) adolescents based on the information obtained from the Niger State Ministry of Education in the Department of Planning and Statistics, Minna Niger State, the sample size for the urban and rural schools was one thousand four hundred $(1,400)$ and four hundred and twenty (420) adolescents, respectively. This summed up to a total sample size of one thousand eight hundred and twenty (1820) adolescents for the survey.

\subsection{Instrument for Data Collection, its Validity and Reliability}

The instrument used for data collection, Psychoactive Substance Abuse Questionnaire (PSAQ) was developed in the course of the study and validated by five (5) experts. Three (3) of the experts were in the Health and Physical Education Department while one (1) each was in the Measurement and Evaluation Department and Educational Psychology Department, all in the University of Nigeria Nsukka. The objectives of the study and research question(s) accompanied the questionnaire to enable the validators determine whether the contents were in line with the objectives of the study. The questionnaire items were structured to supply the substances used among the secondary school adolescents out of eighteen listed psychoactive substances. The respondents were requested to mark $[X]$ in as many options as are applicable to them.

The reliability of the instrument was determined by administering twenty copies of the structured questionnaire twenty secondary school adolescents in Chanchaga LGA of Niger State under close examination. Their responses to the question were scrutinized and found to be devoid of any bias, indicating that questionnaire was quite understandable and usable, hence reliable for this study.

\subsection{Access to Data Collection}

Access to data collection was gained using the letter of introduction which was signed by the Head, Department of Health and Physical Education, University of Nigeria Nsukka and presented to the respective school Principals for permission to access the students. The researcher, with the assistance of some class teachers, administered copies of the questionnaire to the consenting students and ensured that there was no exchange of idea while filling the questionnaire. The filled questionnaires were retrieved on the spot, ensuring hundred percent $(100 \%)$ questionnaire return rate.

\subsection{Questionnaire Return Rate}

Out of 1820 copies of the questionnaire that were distributed, filled and collected (returned), one hundred and one (101) copies were discarded for incomplete filling, and the 
The Demographic Patterns of Psychoactive Substance Abuse among Secondary School Students in Bosso Local Government Area Niger State, Nigeria

remaining 1719 copies were utilized and served as the effective sample size for the study.

\section{Data ANALYSiS}

Chi-square $\chi^{2}$ analyses of the data were carried out using the Statistical Package for Social Sciences [SPSS] for Windows version 16.0 and the result presented based on simple percent and frequency.

\section{Results}

Table1.Gender and age distribution of the respondents (secondary school students in Bosso Local Government Area Niger State, Nigeria)

\begin{tabular}{|l|l|l|l|l|l|l|}
\hline & Males & Females & $\begin{array}{c}\mathbf{1 0} \\
\mathbf{1 3} \\
\text { years }\end{array}$ & $\begin{array}{c}\mathbf{1 4} \\
\mathbf{1 6} \\
\text { years }\end{array}$ & $\begin{array}{l}\mathbf{1 7 - 1 9} \\
\text { years }\end{array}$ & Total \\
\hline Number & 1175 & 544 & 22 & 831 & 866 & 1719 \\
\hline Percentage & 68.35 & 32.65 & 1.28 & 48.34 & 50.38 & 100 \\
\hline Ratio & 3.15 & 1 & & & & \\
\hline
\end{tabular}

As depicted on Table 1, data showed that out of the 1719 valid respondents, 1175 representing $68.35 \%$ were males whereas 544 representing $32.65 \%$ were females. This yielded a Male: Female ratio of 3.15:1. Furthermore, only 22 or $1.28 \%$ of these respondents were in the 10-13 years age bracket whereas the 14-16 years age bracket were $831(48.34 \%)$ and slightly lower

Table2.Percentage Analysis of Demographic Patterns of Common Psychoactive Substances Abused by Adolescents According to Gender and Age $(n=1719)$

\begin{tabular}{|c|c|c|c|c|c|c|c|c|c|c|}
\hline \multirow{3}{*}{ Substance Abuse } & \multicolumn{4}{|c|}{ Gender } & \multicolumn{6}{|c|}{ Age (Years) } \\
\hline & \multicolumn{2}{|c|}{ Male $(n=1175)$} & \multicolumn{2}{|c|}{$\begin{array}{c}\text { Female } \\
(n=544)\end{array}$} & \multicolumn{2}{|c|}{$\begin{array}{c}10-13 \\
(n=22)\end{array}$} & \multicolumn{2}{|c|}{$\begin{array}{c}14-16 \\
(n=831)\end{array}$} & \multicolumn{2}{|c|}{$\begin{array}{c}17-19 \\
(n=866)\end{array}$} \\
\hline & $\mathbf{F}$ & $\%$ & f & $\%$ & $\mathbf{f}$ & $\%$ & f & $\%$ & $\mathbf{F}$ & $\%$ \\
\hline Alcohol(Giya) & 395 & 33.6 & 0 & 0.00 & 0 & 0.00 & 64 & 7.7 & 331 & 38.2 \\
\hline Marijuana & 449 & 38.2 & 0 & 0.00 & 2 & 9.1 & 75 & 9.0 & 372 & 43.0 \\
\hline Cigarette(Taba) & 462 & 39.3 & 0 & 0.00 & 12 & 8.9 & 74 & 43.4 & 376 & 54.5 \\
\hline Cocaine & 89 & 7.6 & 0 & 0.00 & 0 & 0.00 & 64 & 7.7 & 25 & 2.9 \\
\hline Valium & 29 & 2.5 & 0 & 0.00 & 0 & 0.00 & 3 & .4 & 26 & 3.0 \\
\hline Sleeping pills & 207 & 17.6 & 10 & 1.8 & 1 & 4.5 & 174 & 20.9 & 42 & 4.8 \\
\hline Glue & 71 & 6.0 & 0 & 0.00 & 0 & 0.00 & 12 & 1.4 & 59 & 6.8 \\
\hline Paint & 227 & 19.3 & 0 & 0.00 & 0 & 0.00 & 162 & 19.5 & 65 & 7.5 \\
\hline Kola nuts(Goro) & 415 & 35.3 & 542 & 99.6 & 21 & 95.5 & 582 & 70.0 & 354 & 40.9 \\
\hline Codeine/cough syrup & 396 & 33.7 & 6 & 1.1 & 21 & 95.5 & 108 & 13.0 & 273 & 31.5 \\
\hline Petrol & 370 & 68.0 & 198 & 16.9 & 0 & 0.00 & 170 & 19.6 & 398 & 47.9 \\
\hline Gasoline & 188 & 16.0 & 0 & 0.00 & 0 & 0.00 & 162 & 19.5 & 26 & 3.0 \\
\hline Opium & 1 & 0.1 & 0 & 0.00 & 0 & 0.00 & 1 & 0.1 & 0 & 0.00 \\
\hline LSD (Solution) & 59 & 5.0 & 0 & 0.00 & 0 & 0.00 & 1 & 0.1 & 58 & 6.7 \\
\hline Cannabis & 196 & 16.7 & 0 & 0.00 & 0 & 0.00 & 90 & 10.8 & 106 & 12.2 \\
\hline Coffee & 542 & 46.1 & 486 & 89.3 & 1 & 4.5 & 637 & 76.7 & 390 & 45.0 \\
\hline Caffeine & 251 & 21.4 & 0 & 0.00 & 0 & 0.00 & 111 & 13.4 & 140 & 16.2 \\
\hline Amphetamine & 190 & 16.2 & 0 & 0.00 & 0 & 0.00 & 84 & 10.1 & 106 & 12.2 \\
\hline
\end{tabular}

The Chi-square analysis of the difference according to gender was as in Table 4 while that according to age was as in Table 4. There was no statistically significant difference $(p<0.05)$ in the demographic pattern of psychoactive substance abuse among adolescents in Bosso LGA of Niger State. than the 17-19 years age bracket $866(50.38 \%)$ (Table 1).

Percentage analysis of demographic patterns of common psychoactive substances abused by adolescents in the studied area according to gender and age (Table 2) revealed that females abused kola nuts $(99.6 \%)$ and coffee $(89.3 \%)$ more than the male students, whereas higher proportion of males abused almost the surveyed psychoactive substances except opium. And, according to age, substance abuse was higher among the 10-13years age bracket for kola nuts (95.5\%) and codeine/cough syrup (95.5\%) but among the 14-16 age brackets for coffee (76.7\%) only whereas among the 17-19 age brackets cigarette (54.5\%), petrol (47.9\%), marijuana $(43.0 \%)$ and alcohol $(38.2 \%)$ were moderately abused. There was no statistically significant difference in the psychoactive substance abuse according to gender among adolescents except for opium (Table 3). However, there was no statistically significant difference in the psychoactive substance abuse according to age among adolescents except for opium, cannabis and amphetamine (Table 4). 
The Demographic Patterns of Psychoactive Substance Abuse among Secondary School Students in Bosso Local Government Area Niger State, Nigeria

Table3.Summary of Chi-square ( $\left.\chi^{2}\right)$ Analysis of the Difference in Psychoactive Substance Abuse According to Gender

\begin{tabular}{|l|l|l|l|l|l|}
\hline & \multicolumn{1}{|c|}{ Male f } & \multicolumn{1}{c|}{ Female F } & \multicolumn{1}{c|}{$\chi^{2}$ Cal } & Df & P-value \\
\hline Alcohol & 395 & 0 & 237.436 & 1 & .000 \\
\hline Marijuana & 449 & 0 & 281.371 & 1 & .000 \\
\hline Cigarette & 462 & 0 & 292.512 & 1 & .000 \\
\hline Cocaine & 89 & 0 & 43.455 & 1 & .000 \\
\hline Valium & 29 & 0 & 13.657 & 1 & .000 \\
\hline Sleeping pills & 207 & 10 & 83.932 & 1 & .000 \\
\hline Glue & 71 & 0 & 34.288 & 1 & .000 \\
\hline Paint & 227 & 0 & 121.086 & 1 & .000 \\
\hline Kolanuts & 415 & 542 & 623.227 & 1 & .000 \\
\hline Codeine/Cough syrup & 396 & 6 & 220.554 & 1 & .000 \\
\hline Petrol & 198 & 370 & 439.959 & 1 & .000 \\
\hline Gasoline & 188 & 0 & 97.728 & 1 & .000 \\
\hline Opium & 1 & 0 & 0.463 & 1 & .496 \\
\hline LSD & 59 & 0 & 28.287 & 1 & .000 \\
\hline Cannabis & 196 & 0 & 102.422 & 1 & .000 \\
\hline Coffee & 542 & 486 & 288.816 & 1 & .000 \\
\hline Caffeine & 251 & 0 & 136.077 & 1 & .000 \\
\hline Amphetamine & 190 & 0 & 98.897 & 1 & .000 \\
\hline
\end{tabular}

Notes: $\chi 2$ : Table (critical) probability

Table4. Summary of Chi-square $\left(\chi^{2}\right)$ Analysis of the Difference in Psychoactive Substance Abuse According to Age

\begin{tabular}{|c|c|c|c|c|c|c|}
\hline 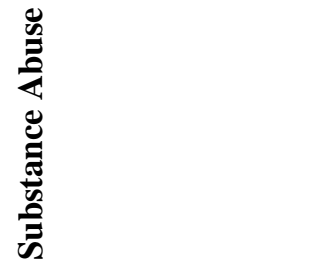 & 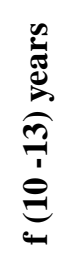 & 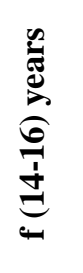 & 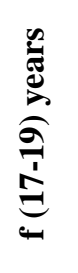 & $\begin{array}{c}\bar{\mho} \\
\chi^{2}\end{array}$ & 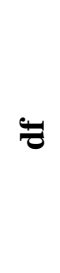 & 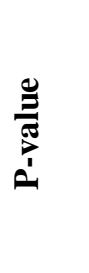 \\
\hline Alcohol & 0 & 64 & 331 & 229.840 & 2 & .000 \\
\hline Marijuana & 2 & 75 & 372 & 256.353 & 2 & .000 \\
\hline Cigarette & 12 & 74 & 376 & 265.709 & 2 & .000 \\
\hline Cocaine & 0 & 64 & 25 & 21.241 & 2 & .000 \\
\hline Valium & 0 & 3 & 26 & 18.2220 & 2 & .000 \\
\hline Sleeping pills & 1 & 174 & 42 & 100.837 & 2 & .000 \\
\hline Glue & $\mathrm{O}$ & 12 & 59 & 31.831 & 2 & .000 \\
\hline Paint & 0 & 162 & 65 & 56.570 & 2 & .000 \\
\hline Kola nuts & 21 & 582 & 354 & 160.393 & 2 & .000 \\
\hline Codeine/Cough syrup & 21 & 108 & 273 & 145.854 & 2 & .000 \\
\hline Petrol & 0 & 398 & 170 & 164.113 & 2 & .000 \\
\hline Gasoline & 0 & 162 & 26 & 121.154 & 2 & .000 \\
\hline Opium & 0 & 1 & 0 & 1.069 & 2 & $.586^{*}$ \\
\hline LSD & 0 & 1 & 58 & 56.140 & 2 & .000 \\
\hline Cannabis & 0 & 90 & 106 & 3.702 & 2 & $.157 *$ \\
\hline Coffee & 1 & 637 & 390 & 204.682 & 2 & .000 \\
\hline Caffeine & 0 & 111 & 140 & 6.494 & 2 & .039 \\
\hline Amphetamine & 0 & 84 & 106 & 4.730 & 2 & $.094 *$ \\
\hline
\end{tabular}

Notes: *: Significant

\section{DISCUSSION}

The demographic patterns of psychoactive substance abuse among secondary school adolescents in Bosso Local Government Area,
Niger State, Nigeria were determined by crosssectional survey design. Data from the respondents $(\mathrm{n}=1820)$, using Psychoactive Substance Abuse Questionnaire (PSAQ) and 
appropriate statistics (Chi-square) at $\mathrm{p}<0.05$ revealed that out of $1719 \quad(100 \%)$ valid respondents, $1175(68.35 \%)$ and $544(32.65 \%)$ respectively were males and females, hence a Male: Female ratio of 3.15. This implied more male adolescent than females in the studied area. Age demography revealed that $22(1.28 \%)$, $831(48.34 \%)$ and $866(50.38 \%)$ were in the 1013 years, 14-16 years and 17-19 years age bracket, respectively. This indicated higher number of adolescent in the 17-19 age bracket followed by 14-16 age bracket.

Percentage analysis according to gender revealed that females abused kola nuts (99.6\%) and coffee $(89.3 \%)$ more than the male students, whereas higher proportion of males abused the other surveyed psychoactive substances except opium. The demographic pattern of common psychoactive substance abuse among adolescents which was generally higher in the males than in the females was as would be expected and indicated that males more than females are prone to abuse these substances in Bosso LGA of Niger State. The observation could be explained based on the prevailing observation in the study area where males were more exposed to life than females. Further to this, reports on gender differences in substance abuse abound ${ }^{[8,18-20]}$. Environment was noted to influence variation in gender in the abuse of substances with highly industrialized cities (unlike the studied area) likely to have more females abusing substances [21]. Thus, the demographic pattern of substance abuse that was higher in males might be related to the low industrialized status of Bosso LGA. It was, therefore, surprising that in the present study the females abused kola nuts and coffee more than the males. This might be due to the relative cheapness, availability and most importantly social acceptability of kola nuts and coffee use. Kola nuts and, in particular, coffee were generally considered acceptable in the society [22].

Percentage analysis according to age revealed that substance abuse was higher among the 1013years age bracket for kola nuts $(95.5 \%)$ and codeine/cough syrup (95.5\%) and among the 1416 age brackets for coffee $(76.7 \%)$ only but moderately abused among the 17-19 age brackets for cigarette $(54.5 \%)$, petrol $(47.9 \%)$, marijuana (43.0\%) and alcohol (38.2\%). These results were surprising and appear to suggest that initiation of use of these substances starts early in adolescence as reported in earlier study
[23]. The higher tendency to abuse multiple substances in the older adolescents might be due to increasing peer influence and exposure to many types of substances with increasing age.

There was no significant difference $(p>0.05)$ in the substance abuse according to gender (except for opium) and according to age (except for opium, cannabis and amphetamines). This was as expected because gender differences in substance use though severally reported have not been consistent amongst various studies ${ }^{[8,18-}$ ${ }^{20]}$. However, the present result contrasted with that of previous reports ${ }^{[24,25]}$ which reported a significant difference between male and female abusers, though in adolescent of up to 25 years. In addition, age difference had no significant difference in all the studied psychoactive substance abuse except opium, cannabis and amphetamine. The results were not surprising. It is a common knowledge that peer pressure and association play significant role on behaviour. Thus, it is paramount that adolescents do not cohabitate with adults who use these psychoactive substances. Similarly, notorious places for substance abuse (including motor parks or hotels) should not be sited close to secondary schools, residential areas or churches where adolescents might witness scene of substance use by adults. Government should set up national orientation agency and health policy. The national orientation agency is expected to educate the adolescents on the dangers of psychoactive substances use whereas the national health policy is expected to effectively control the availability and accessibility of these substances. It is hoped that harnessing these in the design of psychoactive substance abuse intervention programme (SAIP) could go a long way in curbing the menace of substance abuse among adolescents in Bosso LGA of Niger State in particular and indeed Nigeria in general. The findings in this study could be further improved by for instance designing an empirical study to determine some biochemical indicators of substance intoxication in these self-reported adolescent common psychoactive substances abusers.

\section{CONCLUSiON}

The results suggest that the demographic pattern of substance among studied adolescents cuts across their age and gender though higher involvement in male gender and 17-19 years age bracket. It was recommended that parents, school authorities and government should 
disregard age and gender disparity while discouraging the adolescents from substance abuse. The findings in this study could be further improved by for instance designing an empirical study to determine some biochemical indicators of substance intoxication in these self-reported adolescent common psychoactive substances abusers, hence warranted and recommended.

\section{LIMITATIONS}

Characteristics of self-reported survey studies, the results may be limited by deliberate false self-report. Furthermore, a local government area was surveyed and findings may differ in other local government areas hence should not be generalized.

\section{AUTHOR CONTRIBUTIONS}

ACCE approved the version and interpreted the data to be published, ONCE carried out the study and managed the literature searches under supervision while ESS developed the concepts, designed the experiments and supervised the study. All authors read and approved the final manuscript.

\section{ETHICAL APPROVAL}

All authors herby declare that the study was examined and approved by the appropriate ethics committee and was therefore carried out in accordance with the ethical standards laid down in the 1964 declaration of Helsinki.

\section{RFERENCES}

[1] United Nations Drug Control and Crime Prevention (UN-DCCP-2002). World Health Report, New York: Guilpord Press. 2002.

[2] Egbuonu ACC, Ejikeme PM, Ezeanyika LUS, Obidoa O. Combined oral arginine and monosodium glutamate exposure induces adverse response on the prostate function and testis histology of rats. British Journal of Pharmaceutical Research. 2013; 3(2): 247-58.

[3] Ogbu AE, Egbuonu ACC, Ezeanyika LUS. Time and dose dependent effects of esculetin on some routine parameters of biochemical function in male Wistar rats. International Research Journal of Biochemistry and Bioinformatics. 2012; 2(5): 105-08.

[4] Egbuonu ACC, Osakwe ON. Effects of high monosodium glutamate on some serum markers of lipid status in male Wistar rats. Journal of Medicine and Medical Sciences. 2011; 2(1): 653-56.

[5] Egbuonu ACC, Ejikeme PM, Obasi NL. Monosdium glutamate: Potentials at inducing prostate pathologies in male Wistar rats. African Journal of Biotechnology. 2010; 9(36): 5950-54.

[6] Egbuonu ACC, Obidoa O, Ezeokonkwo CA, Ezaeanyika LUS, Ejikeme PM. Low dose oral administration of monosodium glutamate in male albino rats may be nephroprotective. BioResearch. 2009; 7(1): 470-73.

[7] Adelekan ML, Stimson GV. Problems and prospects of implementing harm reduction for HIV and injecting drug use in high risk subsaharan African countries. Journal of Drug Issues. 1997; 27: 97-16.

[8] Abiodun AO, Adelekan ML, Ogunremi OO. Psychosocial correlates of alcohol, tobacco and cannabis use amongst secondary school students in Ilorin, Nigeria. West Afr J Med. 1994;13: 213-17.

[9] Baptista T, Novoa D, Hernandez R. Substance use among Venezuelan medical and pharmacy students. Drug Alcohol Dependence. 1994; 34:12-17.

[10] Bell R. Correlates of college student marijuana use: results of a US National survey. Addiction. 1997; 92: 571-81.

[11] Anochie IC, Nkanginieme K. Social correlatives of drug use among secondary school students in Port Harcourt, southern Nigeria. Sahel Medical Journal. 2000; 3:87-92.

[12] Adelekan ML, Ndom RJE, Makanjuola AB. Trend analysis of substance use among undergraduates of university of Ilorin, Nigeria, 1988-1998. African Journal of Drug Alcohol Studies. 2000; 1:39-52.

[13] Walsh A. Drug use and sexual behaviour: users, experimenters and abstainers. Journal of Social Psychology. 1992; 32: 691-93.

[14] Leibsohn JM. Relationship between drug and alcohol use and peer group association of college freshmen as they transit from high school. Journal of Drug Education. 1994; 24: 177-92.

[15] Egbuonu ACC, Egbuonu ONC, Samuel ES. The prevalence of some psychoactive substances use among secondary school adolescents in Bosso Local Government Area, Nigeria. Journal of Environmental Toxicology and Public Health. 2015; 1(1): 6-10.

[16] Cabrita J, Ferreira H, Iglesias P, Baptista T, Rocha E, Lopes da Silva A et al. Patterns and determination of psychoactive drug use in Lisbon University Students- a population based study. Pharmworld Science. 2004; 26(2):79-82.

[17] Shehu AU, Idris SH. Marijuana smoking among secondary school students in Zaria, Nigeria: Factors Responsible and Effects on Academic Performance. Annals of African Medicine. 2008; 7(4):175-179. 
[18] Anochie IC, Nkanginieme KEO, Eke F, Alikor EAD. Drug abuse among school students in Port Harcourt metropolis. Nigerian Journal of Medicine. 1999; 8:17-23.

[19] Adelekan ML, Makanjuola AB, Ndom RJE. 5yearly monitoring of trends of Substance use among secondary school students in Ilorin, Nigeria 1988-98. West African Journal of Medicine. 2001; 20:28-36.

[20] Omokhodiun FO, Faseru BO. Perception of cigarette smoking and advertisement among senior secondary school students in Ibadan, Southwestern Nigeria. West African Journal of Medicine. 2007; 26:206-09.

[21] Igwe WC, Ojinnaka N, Ejiofor SO, Emechebe GO, Ibe BC. Socio-demographic correlates of psychoactive substance abuse among secondary school students in Enugu, Nigeria. European Journal of Social Sciences. 2009; 12(2): 27783.

[22] Oshikoya KA, Alli A. Perception of drug abuse amongst Nigerian undergraduates. World Journal of Medical Sciences. 2006; 1(2):13339.

[23] Eneh AU, Stanley PC. Pattern of substance abuse among secondary school students in Rivers state of Nigeria. Nigerian Journal of Medicine. 2004; 13(2):36-39. Oliha JA. Adolescent and drug abuse in tertiary institution implication for counseling. British Journal of Education. 2014; 2(1):1-9.

[24] Enakpoya E. Prevalence of drug abuse among Nigerian adolescents: Implication for counseling. The Counsellor. 2009; 26(2): 1-7.

Citation: Onyinye Nkiru C. Egbuonu, Anthony Cemaluk C. Egbuonu \& Efiong S. Samuel. The Demographic Patterns of Psychoactive Substance Abuse among Secondary School Students in Bosso Local Government Area Niger State, Nigeria. ARC Journal of Public Health and Community Medicine.2017; 2(4):37-43. DOI: dx.doi.org/ 10.20431/2456-0596.0204007.

Copyright: (C) 2017 Authors. This is an open-access article distributed under the terms of the Creative Commons Attribution License, which permits unrestricted use, distribution, and reproduction in any medium, provided the original author and source are credited. 